\title{
Tracking Groundwater Levels using the Ambient Seismic Field
}

\author{
Timothy Clements ${ }^{1}$, Marine A. Denolle ${ }^{1}$
}

${ }^{1}$ Department of Earth and Planetary Sciences, Harvard University, Cambridge, MA

\section{Key Points:}

- Groundwater levels in the San Gabriel Valley Basin, California reach all-time low after 2011-2016 drought

- Seismic velocities respond linearly with drawdown and recharge of ground water aquifer

- Time-dependent maps of seismic velocity change yield high temporal and spatial resolution maps of groundwater levels 


\begin{abstract}
Aquifers are vital groundwater reservoirs for residential, agricultural, and industrial activities worldwide. Tracking their state with high temporal and spatial resolution is critical for water resource management at the regional scale yet is rarely achieved from a single dataset. Here, we show that variations in groundwater levels can be mapped using perturbations in seismic velocity $(d v / v)$. We recover daily measurements of $d v / v$ in the San Gabriel Valley, California, from cross correlation of the ambient seismic field. $d v / v$ reproduces the groundwater level changes that are marked by the multi-year depletions and rapid recharges typical of California's cycles of droughts and floods. $d v / v$ correlates spatially with vertical surface displacements and deformation measured with GPS. Our results successfully predict the volume of water lost in the San Gabriel Valley during the 2012-2016 drought and thus provide a new approach to monitor groundwater storage.
\end{abstract}

\title{
1 Introduction
}

Groundwater supplies one third of the fresh water used for residential, agricultural, and industrial use in the world [Döll et al., 2012]. With increasing demand, over-withdrawal of groundwater has lead to subsidence and a loss of groundwater storage in numerous aquifers across the world [Galloway and Burbey, 2011]. This is especially problematic for more than two billion people worldwide that live farther than $5 \mathrm{~km}$ from a source of surface fresh water [Китти et al., 2011]. Compounding this is the role of climate change, which has lead to more frequent and pronounced dry and hot years, along with stronger extreme precipitation events in places like California [Swain et al., 2016; Teng and Branstator, 2017; Dettinger et al., 2011]. Accurate monitoring of groundwater levels is required to manage water supplies, yet comprehensive groundwater level measurements on the local to global scales are lacking Wada et al. [2010], especially in the context of climate change [Taylor et al., 2012]. Surface displacements measured by GPS provide high temporal but sparse spatial resolution of groundwater level changes [Bawden et al., 2001; King et al., 2007; Ji and Herring, 2012], while those measured by Interferometric Synthetic-Aperture Radar (InSAR) bring high spatial resolution but limited temporal resolution [King et al., 2007; Galloway and Hoffmann, 2007; Chaussard et al., 2017]. Gravity measurements from the GRACE satellite are sensitive to water mass changes, but only at large wavelengths and they suffer non-uniqueness between water mass and aquifer depths [Rodell et al., 2009; Xiao et al., 2017].

The cross-correlation of ambient seismic time series [Shapiro and Campillo, 2004; Campillo, 2006] can remedy these issues by providing high spatial and temporal resolution of the change in bulk seismic velocity, $d v / v$, within a groundwater basin. $d v / v$ has been widely used in recent years to study the dynamics of Earth's crust in response to earthquakes [Brenguier et al., 2008a; Wegler et al., 2009; Taira et al., 2015], volcanic eruptions [Brenguier et al., 2008b] and ice sheet melt [Mordret et al., 2015]. Seasonal variations from precipitation [Sens-Schönfelder and Wegler, 2006; Meier et al., 2010; Tsai, 2011; Wang et al., 2017], air temperature changes [Meier et al., 2010; Tsai, 2011; Hillers et al., 2015], freezethaw of permafrost [James et al., 2017] and long-term variations from climatic forcing [Lecocq et al., 2017] are known to influence shallow seismic wavespeeds. $d v / v$ is conducive to monitoring groundwater levels, as the velocity of seismic waves that scattered within watersaturated rocks is sensitive to changes in pore pressure [Grêt et al., 2006]. Increasing pore pressure opens cracks and decreases the area of grain contacts, which in turns decreases seismic velocity [Christensen and Wang, 1985]. Seismic waves naturally scatter in the Earth and provide an averaged and volumetric sampling of the medium. This contrasts with measurements from a ground water well, which are sensitive to a specific location [Healy and Cook, 2002] that may not be representative of the aquifer if the permeability structure is heterogeneous.

This study presents the perturbations in bulk seismic velocity $(d v / v)$ in the San Gabriel Valley (SGV), Eastern Los Angeles County, California. The SGV contains three unconfined, 
urban aquifers: the San Gabriel, the Puente, and the Raymond Basins. The east-northeaststriking Raymond Fault acts as a barrier to flow between the Raymond and San Gabriel Basins, while the San Gabriel and Puente Basins are hydraulically connected [California Department of Water Resources, 1966; Yeats, 2004; Main San Gabriel Watermaster, 2017]. Water-bearing sediments reach a maximum thickness of $1,200 \mathrm{~m}$ in the central part of the SGV [California Department of Water Resources, 1966]. The SGV Basin is recharged by a combination of infiltration from rainfall, runoff from the San Gabriel Mountains, stormwater capture, and imported water from the State Water Project. During droughts, groundwater supplies over 40\% of water demand in the SGV [Main San Gabriel Watermaster, 2017]. We consider changes in SGV groundwater in the period Jan 2000 - Jul 2017. This period is notable for having three major droughts in southern California (2002-2004, 2007-2009, and 2012-2016) [California Department of Water Resources, 2015]. During the most recent drought, groundwater levels dropped $18 \mathrm{~m}$ in the SGV in the Baldwin Park Key Well (Fig. 1.), reaching all-time low levels in Oct 2016. Even with above average precipitation in the winter of 2016-2017, groundwater levels have only recovered $1.7 \mathrm{~m}$ in the SGV basin due to uptake by drought-parched soil [Main San Gabriel Watermaster, 2017].

\section{Data and Methods}

\section{Ambient Seismic Cross-Correlation}

We use continuous data from broad-band vertical component seismometers in the California Integrated Seismic Network (CI) from Jan 2000 - Jul 2017 (Fig 1.). All raw waveforms are downsampled to $20 \mathrm{~Hz}$, demeaned, and detrended. We apply one-bit normalization and whiten in the frequency domain from 0.05 to $4 \mathrm{~Hz}$ [Bensen et al., 2007; Lecocq et al., 2017]. Daily time series are segmented into 1-hour windows with 30 minutes of overlap between successive windows and cross-correlated using the MSNoise package [Lecocq et al., 2014]. NCFs are computed for all station pairs in all available data ranges. Instrument corrections are applied after cross-correlating. Hourly windows of raw data with maximum absolute amplitude greater than ten times the standard deviation of the daily trace are discarded. A daily NCF is formed by stacking all hourly NCFs from each day.

Daily changes in seismic velocity are computed using the Moving Window CrossSpectrum (MWCS) technique [Poupinet et al., 1984; Clarke et al., 2011]. This technique, unlike the stretching technique of Sens-Schönfelder and Wegler [2006], does not assume a global, linear time shift in phase arrival and is less susceptible to temporal variations in the source of seismic noise [Zhan et al., 2013]. We compute time shifts, $d t$, in the coda of daily NCFs relative to a reference NCF, the stack of all NCFs for each station pair, in the $0.1-0.25$ $\mathrm{Hz}$ and $0.5-2 \mathrm{~Hz}$ frequency bands. For each day, the previous 30 days of NCFs are stacked to improve the stability of the MWCS analysis. Time shifts $d t$ and coherency $c$ between the reference and daily NCF are calculated beginning after the $0.5 \mathrm{~km} / \mathrm{s}$ arrival in the coda in $30 s$ windows for $0.1-0.25 \mathrm{~Hz}$ and $10 \mathrm{~s}$ windows for $0.5-2 \mathrm{~Hz}$, shifted by $20 \%$ of the window length. $d t$ measurements with time shift $d t \leq 0.2 \mathrm{~s}$ in each window and coherency $c \geq 0.5$ are included. A daily time shift $d t / t$ is measured by regressing time shifts $d t$ from each window in the causal and acausal part of the coda. Assuming that there is linear relation between relative time lags and that the velocity change is homogeneous throughout the sampling medium, the daily velocity variation is just $-d t / t=d v / v$.

\section{$d v / v$ Regionalization}

We map $d v / v$ spatially in $1220 \mathrm{~m} \times 905 \mathrm{~m}$ grid cells in the $0.5-2.0 \mathrm{~Hz}$ frequency band using the regionalization method of Brenguier et al. [2008b], which approximates the sensitivity of each station pair as an ellipse. $d v / v$ in all grid cells within $3 \mathrm{~km}$ of the straight line path between each station pair are set as the difference in $d v / v$ between the starting and end date of the period of interest. We then average all grid cells over all station pairs. A gaussian smoothing function has been applied to the $d v / v$ maps in Fig 3. and 4. We did not use the 
sensitivity kernels of Obermann et al. [2013] that assume homogeneous diffuse properties, which are unlikely to be satisfied in resonating sedimentary basins.

\subsection{Water Storage from $d v / v$.}

We calculate the change in groundwater storage $d V_{w}$ in a particular region in the SGV basin from $d v / v$ using

$$
d V_{w}=S_{y} A \Delta_{d v / v} \beta
$$

where $S_{y}$ is the specific yield, $A$ is the area of a grid cell in the regionalization of $d v / v$, $\Delta_{d v / v}$ is the change in seismic velocity in a grid cell between two dates, and $\beta$ is the ratio of a unit change in hydraulic head, $\Delta h$, to a unit change in $\Delta_{d v / v}$ [Fitts, 2013]. The product $\Delta_{d v / v} \beta=\Delta h$ gives the average change in hydraulic head in a grid cell. $S_{y}$ varies from 0.03 to 0.24 across the SGV, with averages of $0.14,0.08$ and 0.09 in the central, eastern, and western parts of the SGV, respectively [California Department of Water Resources, 1966]. We take $S_{y}=0.12$ as a representative, average value for the entire SGV basin. Assuming that the inflation of the aquifer was totally elastic [King et al., 2007], we use the 2005 rain event (Jan 1 - Jun 12005 ) to calibrate $\beta$ for the SGV. A $16.8 \mathrm{~m}$ increase in groundwater level in the Key Well and $-0.00125(-0.125 \%)$ change in $d v / v$ for the SGV basin gives a value of $\beta=-13280 \frac{\mathrm{m}}{\left(\frac{\mathrm{m} / \mathrm{s}}{\mathrm{m} / \mathrm{s}}\right)}$. We find a similar negative value of $\beta=-10900 \frac{\mathrm{m}}{\left(\frac{\mathrm{m} / \mathrm{s}}{\mathrm{m} / \mathrm{s}}\right)}$ using the $d v / v$ and groundwater level changes found by Lecocq et al. [2017]. We integrate $d V_{w}$ over all grid cells to get a total volume change within the SGV basin.

\section{Results and Discussion}

The $d v / v$ variations we measure in the $0.5-2.0 \mathrm{~Hz}$ frequency range, which is greatly sensitive to the upper $1,000 \mathrm{~m}$ of the basin, are the most promising for groundwater monitoring at basin-scale [Obermann et al., 2013]. The change in groundwater level in the Baldwin Park Key Well explains most of the variance in the evolution of $d v / v$ in the SGV. We observe three distinct functional forms in our $d v / v$ measurements : 1) seasonal periodicity, 2) impulsive events, and 3) multi-year linear trends (Fig 2.).

Seasonality in $d v / v$ has been observed recently throughout Japan [Wang et al., 2017], where precipitation (snow or water), sea level changes, and thermal effects were identified as probable mechanisms for seasonality in $d v / v$. Thermo-elastic strains were previously invoked to be responsible for seasonality in $d v / v$ in the Los Angeles Basin from Jan 2001 - Jan 2004 [Meier et al., 2010], and in some cases the greatest contributer to the seasonal signal in the San Jacinto Fault area, California [Hillers et al., 2015]. We use a thermo-elastic model [Tsai, 2011] to remove seasonal $d v / v$ due to surface temperature variations (Fig. 2.). We find that seasonal thermo-elastic strains induce perturbations in wavespeed of about $0.03 \%$, much lower than the hydrological effects that perturb elastic wavespeeds that are about $0.15 \%$. The seasonal residual in $d v / v$ we measure is thus a component of the seasonal recharge in groundwater within the SGV basin [Jasechko et al., 2014].

At the end of 2004, groundwater levels in the SGV were at an all-time low in the Baldwin Park Key Well since measurements began in 1932. In contrast, the winter of 2004-2005 recorded the largest rainfall in a 100-year period in Los Angeles with $1 \mathrm{~m}$ of total precipitation. Water levels in the Baldwin Park Key Well increased by over $16 \mathrm{~m}$ in a span of five months. GPS stations recorded more than $40 \mathrm{~mm}$ of uplift in the central part of the SGV [King et al., 2007; Ji and Herring, 2012]. We find that $d v / v$ decreased by $0.15 \%$ in the same time frame. This impulsive drop in $d v / v$ is similar to that seen after nearby earthquakes [Brenguier et al., 2008a; Wegler et al., 2009]. The largest decrease in $d v / v$ is mapped in the center of the SGV (Fig. 3), where the basin is deepest [Yeats, 2004], as were the largest deformations recorded with InSAR [King et al., 2007]. There is no statistically significant phase lag 
between the groundwater levels and and $d v / v$ response, suggesting a pure elastic response of the aquifer.

$d v / v$ due to groundwater level changes have been observed before [Sens-Schönfelder and Wegler, 2006], but not in the context of water resource management or drought. Recently, Lecocq et al. [2017] found that thermo-elastic strains, including those induced by long-term warming, and hydrologic loading contributed equally to $d v / v$ over 30 years, due to relatively low fluctuations in groundwater levels, in the Grafenburg region, Germany. Here, the dominant process that impacts the variations in elastic wavespeed is the multi-year drawdown during periods of low precipitation [Teng and Branstator, 2017]. During the drought of 2012-2016, groundwater levels declined in the SGV at a rate of $450 \mathrm{~mm} / \mathrm{yr}$, which is one of the highest rates seen globally [Wada et al., 2010]. The largest change in $d v / v$ during the drought occurred at two stations located within the basin and atop the thickest part of the aquifer [California Department of Water Resources, 1966]. During the period Jan 2012- Jan 2017 , when additional well data is available throughout the SGV, we find spatial correlation between the change in $d v / v$ and spatial and temporal patterns of groundwater change. The strongest increase of $d v / v$ occurs in the south of the SGV (Fig. 4.). A small decrease in $d v / v$ during the same time frame suggests that the SGV and Raymond basins are hydraulically separated [California Department of Water Resources, 1966; Ji and Herring, 2012]. GPS stations during the same time period measured a contraction of the ground surface that may result from a elastic response of the basin.

The strong temporal correlation between groundwater levels in the Baldwin Park Key Well and $d v / v$ (Fig. 2.) and spatial agreement between GPS displacements and well levels at key periods of time provide us confidence to map the change in groundwater level. We use the instantaneous elastic response of the 2005 rainfall event to calibrate the conversion between $d v / v$ and groundwater level. Applying this calibration factor to the regionalization of $d v / v$ from Jan 2012 - Jan 2017 yields a water storage loss of $0.48 \mathrm{~km}^{3}$. This matches well with the $0.45-0.5 \mathrm{~km}^{3}$ of water that was pumped by from the main SGV Basin during the drought to meet water demand [Main San Gabriel Watermaster, 2017].

Our results imply that the change in seismic velocity, $d v / v$, has tremendous potential to monitor groundwater fluctuations in basins of moderate-size aquifers. Our analysis is able to provide the water volume change, at much higher spatial resolution than GRACE data. It has also the capabilities to provide a direct and continuous monitoring of the spatial variations in ground water levels, bypassing the need to deploy multiple groundwater wells and performing GPS inversions.

\section{Acknowledgments}

Waveform data was accessed from the Southern California Earthquake Data Center (https://doi.org/10.7914/SN/CI). Groundwater data was accessed from the Los Angeles County Department of Public Works (http://ladpw.org/wrd/) and San Gabriel Watermaster (http://www.watermaster.org/). GPS time series data was accessed from NASA's Crustal Dynamics Data Information System (ftp://cddis.gsfc.nasa.gov/pub/GPS_Explorer/latest/). Weather data was accessed from the Western Regional Climate Center (https://wrcc.dri.edu/). The ObsPy, PyASDF, MPI4Py, SciPy ecosystem and MSNoise packages were used to process data. The computations in this paper were run on the Odyssey cluster supported by the FAS Division of Science, Research Computing Group at Harvard University. The authors would like to thank Loïc Viens, Aurelien Mordret, Michel Campillo, Victor Tsai, and James Rice for thoughtful and helpful discussions. T.C. analyzed the data (seismic, ground water, GPS), created the figures, and wrote the manuscript. M.D. funded the research and edited the manuscript. M.D. and T.C. designed the project. 


\section{References}

Bawden, G. W., W. Thatcher, R. S. Stein, K. W. Hudnut, and G. Peltzer (2001), Tectonic contraction across Los Angeles after removal of groundwater pumping effects, Nature, 412(6849), 812-815, doi:10.1038/35090558.

Bensen, G. D., M. H. Ritzwoller, M. P. Barmin, A. L. Levshin, F. Lin, M. P. Moschetti, N. M. Shapiro, and Y. Yang (2007), Processing seismic ambient noise data to obtain reliable broad-band surface wave dispersion measurements, Geophysical Journal International, 169(3), 1239-1260, doi:10.1111/j.1365-246X.2007.03374.x.

Brenguier, F., M. Campillo, C. Hadziioannou, N. M. Shapiro, R. M. Nadeau, and E. Larose (2008a), Postseismic Relaxation Along the, Science, 321(September), 1478-1481, doi: 10.1126/science. 1160943 .

Brenguier, F., N. Shapiro, M. Campillo, V. Ferrazzini, Z. Duputel, O. Coutant, and A. Nercessian (2008b), Towards forecasting volcanic eruptions using seismic noise, Nature Geoscience, 1(2), 126-130, doi:10.1038/ngeo104.

California Department of Water Resources (1966), Planned utilization of ground water basins: San Gabriel Valley, Tech. rep., Sacramento, Calififornia.

California Department of Water Resources (2015), California's Most Significant Drought: Comparing Historical and Recent Conditions, Tech. rep., Sacramento, Calififornia.

Campillo, M. (2006), Phase and correlation in 'random' seismic fields and the reconstruction of the green function, Pure and Applied Geophysics, 163(2-3), 475-502, doi: 10.1007/s00024-005-0032-8.

Chaussard, E., P. Milillo, R. Bürgmann, D. Perissin, E. J. Fielding, and B. Baker (2017), Remote Sensing of Ground Deformation for Monitoring Groundwater Management Practices: Application to the Santa Clara Valley During the 2012-2015 California Drought, Journal of Geophysical Research: Solid Earth, pp. 8566-8582, doi: 10.1002/2017JB014676.

Christensen, N. I., and H. F. Wang (1985), Influence of pore pressure and confining pressure on dynamic elastic properties of Berea sandstone , doi:http://dx.doi.org/10.1016/01489062(86)90438-9.

Clarke, D., L. Zaccarelli, N. M. Shapiro, and F. Brenguier (2011), Assessment of resolution and accuracy of the Moving Window Cross Spectral technique for monitoring crustal temporal variations using ambient seismic noise, Geophysical Journal International, 186(2), 867-882, doi:10.1111/j.1365-246X.2011.05074.x.

Dettinger, M. D., F. M. Ralph, T. Das, P. J. Neiman, and D. R. Cayan (2011), Atmospheric Rivers, Floods and the Water Resources of California, Water, 3(4), 445-478, doi: 10.3390/w3020445.

Döll, P., H. Hoffmann-Dobrev, F. Portmann, S. Siebert, A. Eicker, M. Rodell, G. Strassberg, and B. Scanlon (2012), Impact of water withdrawals from groundwater and surface water on continental water storage variations, Journal of Geodynamics, 59-60, 143-156, doi: 10.1016/j.jog.2011.05.001.

Fitts, C. R. (2013), Groundwater, in Groundwater Science, pp. 1-22, Elsevier, doi: 10.1016/B978-0-12-384705-8.00001-7.

Galloway, D. L., and T. J. Burbey (2011), Review: Regional land subsidence accompanying groundwater extraction, Hydrogeology Journal, 19(8), 1459-1486, doi:10.1007/s10040011-0775-5.

Galloway, D. L., and J. Hoffmann (2007), The application of satellite differential SAR interferometry-derived ground displacements in hydrogeology, Hydrogeology Journal, 15(1), 133-154, doi:10.1007/s10040-006-0121-5.

Grêt, A., R. Snieder, and J. Scales (2006), Time-lapse monitoring of rock properties with coda wave interferometry, Journal of Geophysical Research: Solid Earth, 111(3), 1-11, doi:10.1029/2004JB003354.

Healy, R. W., and P. G. Cook (2002), Using groundwater levels to estimate recharge, Hydrogeology Journal, 10(1), 91-109, doi:10.1007/s10040-001-0178-0. 
Hillers, G., Y. Ben-Zion, M. Campillo, and D. Zigone (2015), Seasonal variations of seismic velocities in the San Jacinto fault area observed with ambient seismic noise, Geophysical Journal International, 202(2), 920-932, doi:10.1093/gji/ggv151.

James, S. R., H. A. Knox, R. E. Abbott, and E. J. Screaton (2017), Improved moving window cross-spectral analysis for resolving large temporal seismic velocity changes in permafrost, Geophysical Research Letters, 44(9), 4018-4026, doi:10.1002/2016GL072468.

Jasechko, S., S. J. Birks, T. Gleeson, Y. Wada, P. J. Fawcett, Z. D. Sharp, J. J. McDonnell, and J. M. Welker (2014), The pronounced seasonality of global groundwater recharge, Water Resources Research, 50(11), 8845-8867, doi:10.1002/2014WR015809.

$\mathrm{Ji}, \mathrm{K}$. H., and T. A. Herring (2012), Correlation between changes in groundwater levels and surface deformation from GPS measurements in the San Gabriel Valley, California, Geophysical Research Letters, 39(1), 1-5, doi:10.1029/2011GL050195.

King, N. E., D. Argus, J. Langbein, D. C. Agnew, G. Bawden, R. S. Dollar, Z. Liu, D. Galloway, E. Reichard, A. Yong, F. H. Webb, Y. Bock, K. Stark, and D. Barseghian (2007), Space geodetic observation of expansion of the San Gabriel Valley, California, aquifer system, during heavy rainfall in winter 2004-2005, Journal of Geophysical Research: Solid Earth, 112(3), 1-11, doi:10.1029/2006JB004448.

Kummu, M., H. de Moel, P. J. Ward, and O. Varis (2011), How close do we live to water? a global analysis of population distance to freshwater bodies, PLOS ONE, 6(6), doi: 10.1371/journal.pone.0020578.

Lecocq, T., C. Caudron, and F. Brenguier (2014), MSNoise, a Python Package for Monitoring Seismic Velocity Changes Using Ambient Seismic Noise, Seismological Research Letters, 85(3), 715-726, doi:10.1785/0220130073.

Lecocq, T., L. Longuevergne, H. A. Pedersen, F. Brenguier, and K. Stammler (2017), Monitoring ground water storage at mesoscale using seismic noise: 30 years of continuous observation and thermo-elastic and hydrological modeling, Scientific Reports, 7(1), 1-16, doi:10.1038/s41598-017-14468-9.

Main San Gabriel Watermaster (2017), 2016 - 2017 Annual Report, Tech. rep., Azusa, California.

Meier, U., N. M. Shapiro, and F. Brenguier (2010), Detecting seasonal variations in seismic velocities within Los Angeles basin from correlations of ambient seismic noise, Geophysical Journal International, 181(2), 985-996, doi:10.1111/j.1365-246X.2010.04550.x.

Mordret, A., T. D. Mikesell, C. Harig, B. P. Lipovsky, and A. Prieto (2015), Monitoring South-West Greenland's ice sheet melt with ambient seismic noise, Science Advances, (May), 1-11, doi:10.1126/sciadv.1501538.

Obermann, A., T. Planès, E. Larose, C. Sens-Schönfelder, and M. Campillo (2013), Depth sensitivity of seismic coda waves to velocity perturbations in an elastic heterogeneous medium, Geophysical Journal International, 194(1), 372-382, doi:10.1093/gji/ggt043.

Poupinet, G., W. L. Ellsworth, and J. Frechet (1984), Monitoring velocity variations in the crust using earthquake doublets: An application to the Calaveras Fault, California, Journal of Geophysical Research, 89(B7), 5719, doi:10.1029/JB089iB07p05719.

Rodell, M., I. Velicogna, and J. S. Famiglietti (2009), Satellite-based estimates of groundwater depletion in India, Nature, 460(7258), 999-1002, doi:10.1038/nature08238.

Sens-Schönfelder, C., and U. Wegler (2006), Passive image interferemetry and seasonal variations of seismic velocities at Merapi Volcano, Indonesia, Geophysical Research Letters, 33(21), 1-5, doi:10.1029/2006GL027797.

Shapiro, N. M., and M. Campillo (2004), Emergence of broadband Rayleigh waves from correlations of the ambient seismic noise, Geophysical Research Letters, 31(7), 8-11, doi: 10.1029/2004GL019491.

Swain, D. L., D. E. Horton, D. L. Swain, D. E. Horton, D. Singh, and N. S. Diffenbaugh (2016), Trends in atmospheric patterns conducive to seasonal precipitation and temperature extremes in California seasonal precipitation and temperature extremes, (April), 1-14, doi:10.1126/sciadv.1501344. 
Taira, T., F. Brenguier, and Q. Kong (2015), Ambient noise-based monitoring of seismic velocity changes associated with the $2014 \mathrm{Mw} 6.0$ South Napa earthquake, (September 2010), 6997-7004, doi:10.1002/2015GL065308.Received.

Taylor, R. G., B. Scanlon, P. Döll, M. Rodell, R. van Beek, Y. Wada, L. Longuevergne, M. Leblanc, J. S. Famiglietti, M. Edmunds, L. Konikow, T. R. Green, J. Chen, M. Taniguchi, M. F. P. Bierkens, A. MacDonald, Y. Fan, R. M. Maxwell, Y. Yechieli, J. J. Gurdak, D. M. Allen, M. Shamsudduha, K. Hiscock, P. J.-F. Yeh, I. Holman, and H. Treidel (2012), Ground water and climate change, Nature Climate Change, 3(4), 322-329, doi:10.1038/nclimate1744.

Teng, H., and G. Branstator (2017), Causes of extreme ridges that induce california droughts, Journal of Climate, 30(4), 1477-1492, doi:10.1175/JCLI-D-16-0524.1.

Tsai, V. C. (2011), A model for seasonal changes in GPS positions and seismic wave speeds due to thermoelastic and hydrologic variations, Journal of Geophysical Research: Solid Earth, 116(4), 1-9, doi:10.1029/2010JB008156.

Wada, Y., L. P. Van Beek, C. M. Van Kempen, J. W. Reckman, S. Vasak, and M. F. Bierkens (2010), Global depletion of groundwater resources, Geophysical Research Letters, 37(20), 1-5, doi:10.1029/2010GL044571.

Wang, Q. Y., F. Brenguier, M. Campillo, A. Lecointre, T. Takeda, and Y. Aoki (2017), Seasonal Crustal Seismic Velocity Changes Throughout Japan, Journal of Geophysical Research: Solid Earth, 122(10), 7987-8002, doi:10.1002/2017JB014307.

Wegler, U., H. Nakahara, C. Sens-Schönfelder, M. Korn, and K. Shiomi (2009), Sudden drop of seismic velocity after the $2004 \mathrm{Mw} 6.6$ mid-Niigata earthquake, Japan, observed with Passive Image Interferometry B06305, Journal of Geophysical Research: Solid Earth, 114(6), 1-11, doi:10.1029/2008JB005869.

Xiao, M., A. Koppa, Z. Mekonnen, B. R. Pagán, S. Zhan, Q. Cao, A. Aierken, H. Lee, and D. P. Lettenmaier (2017), How much groundwater did California's Central Valley lose during the 2012-2016 drought?, Geophysical Research Letters, pp. 1-8, doi: 10.1002/2017GL073333.

Yeats, R. S. (2004), Tectonics of the san gabriel basin and surroundings, Southern California, Bulletin of the Geological Society of America, 116(9-10), 1158-1182, doi: 10.1130/B25346.1.

Zhan, Z., V. C. Tsai, and R. W. Clayton (2013), Spurious velocity changes caused by temporal variations in ambient noise frequency content, Geophysical Journal International, 194(3), 1574-1581, doi:10.1093/gji/ggt170. 


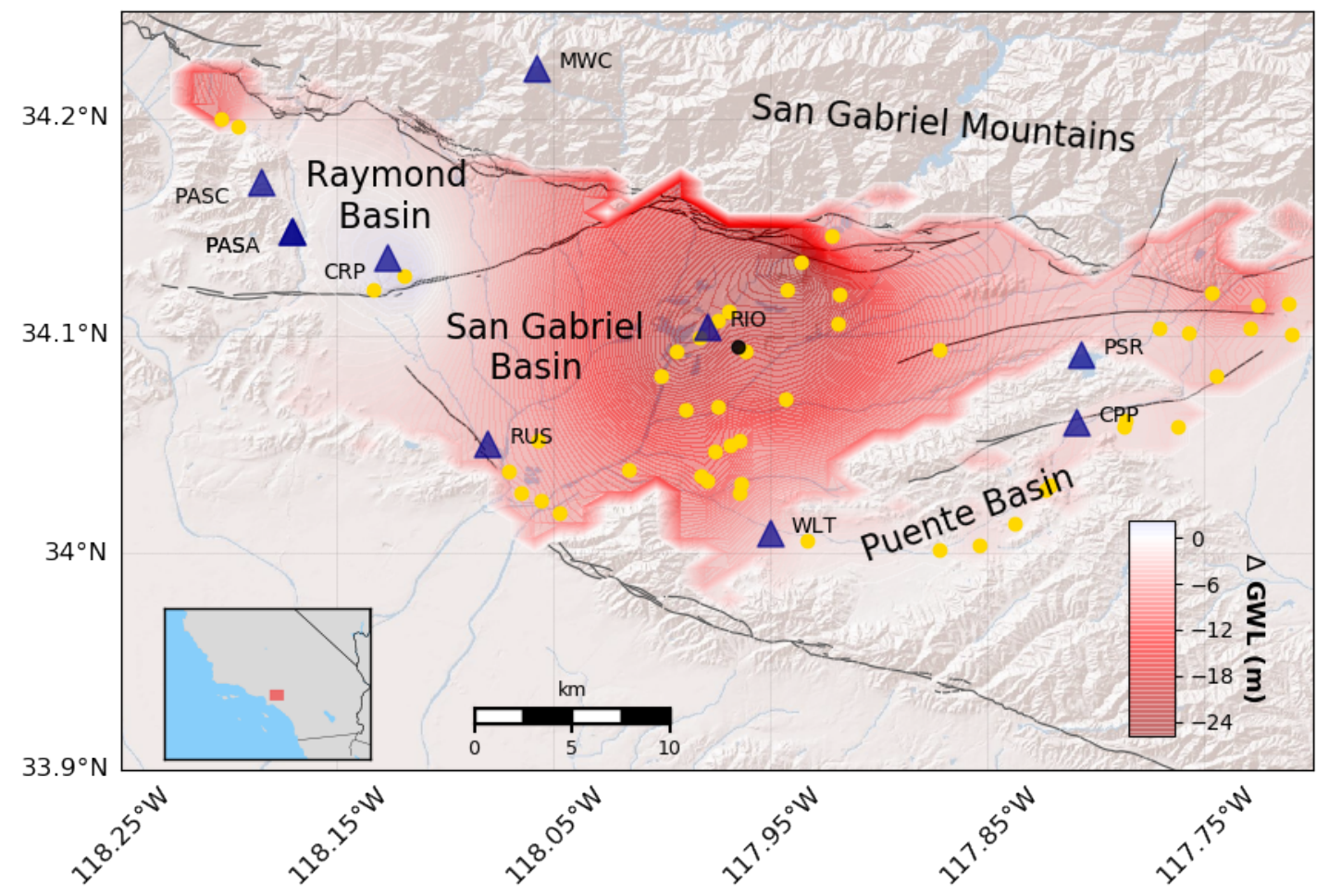

Figure 1. Groundwater level change in San Gabriel Valley during most recent drought (Fall 2012 - Fall 2016). Seismic stations are shown as blue triangles, and groundwater wells are shown as yellow circles. Black circle indicates the position of the Baldwin Park Key well.

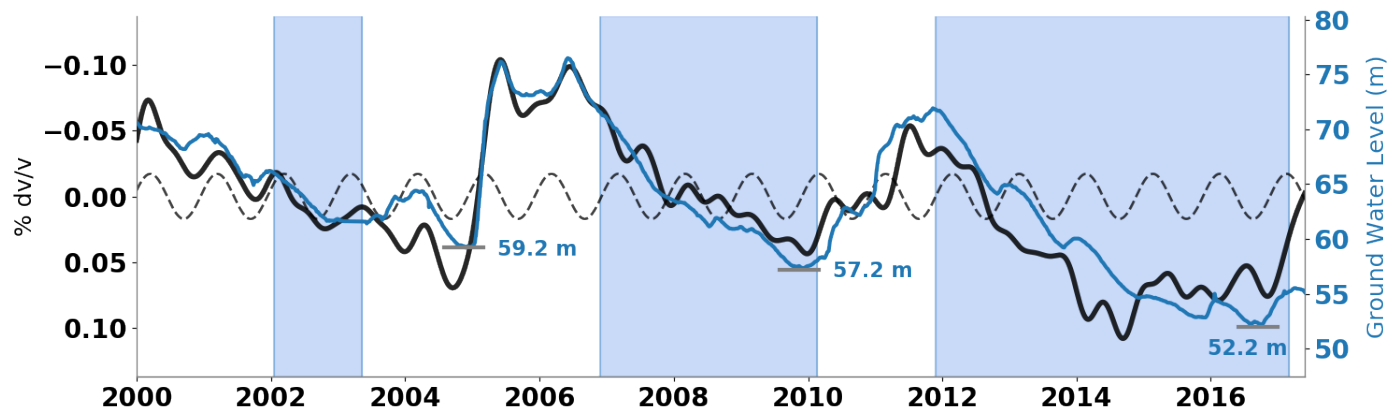

Figure 2. Relating seismic wavespeed temporal perturbation to ground water levels. Observed $d v / v$ stacked over all station pairs (black) with modeled $d v / v$ due to thermo-elastic strain (dashed) removed compared with groundwater change (blue) in the Baldwin Park Key Well. Grey bars indicate lowest historical water levels of the Baldwin Park Key Well. Blue patches indicate times of drought. 


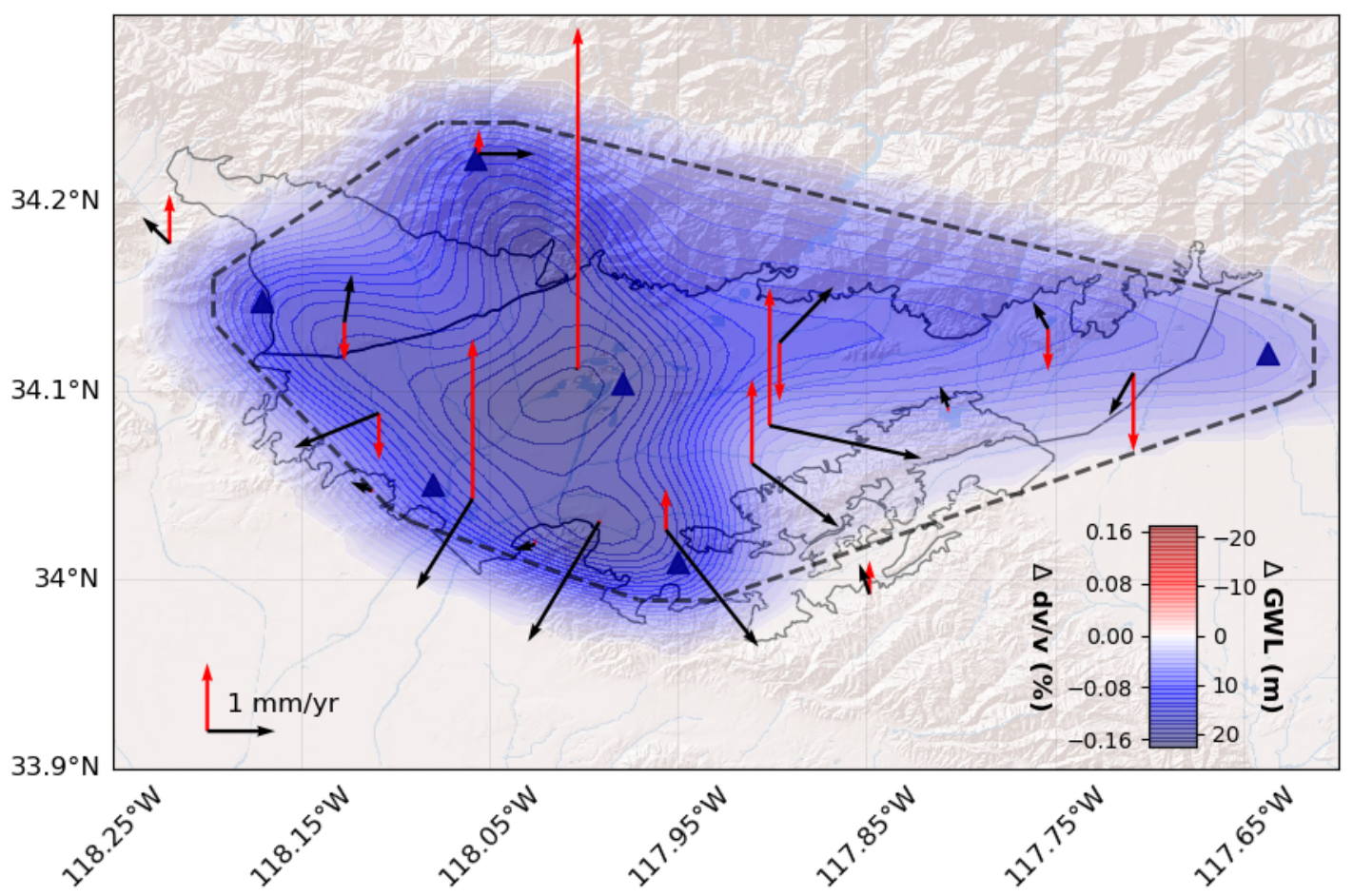

Figure 3. $d v / v$ and GPS measurements after the 2005 Rain Event. Regionalization of $d v / v$ changes Jan 2005 - Jun 2005 following large precipitation event in the SGV. GPS stations (red = vertical, black = horizontal) uplift and move away from center of aquifer. The dashed black lines indicate extent of ray coverage. Scaling of $d v / v$ and groundwater level is from 2005 rain event. 


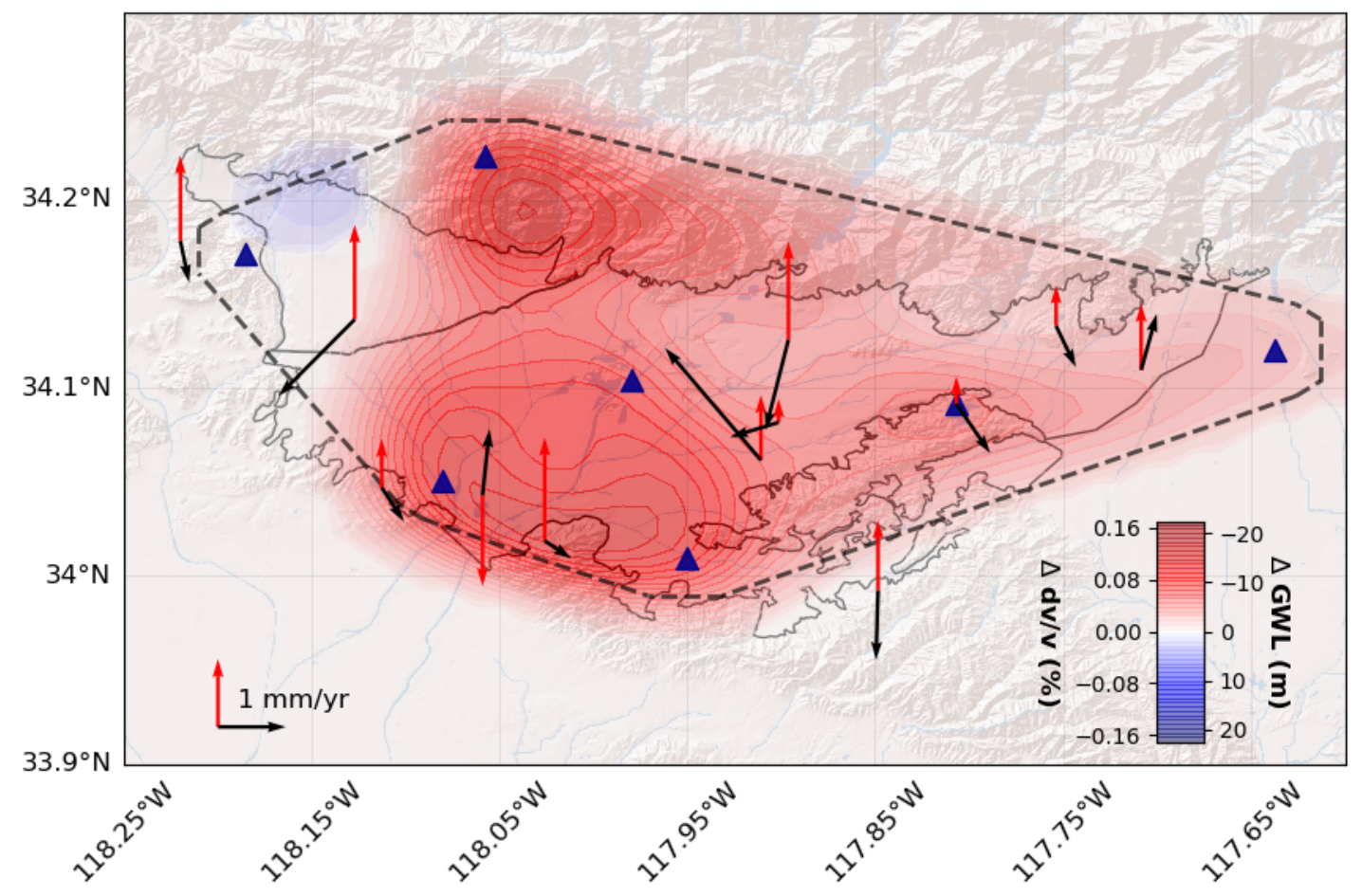

Figure 4. $\quad d v / v$ and GPS measurements after 2012-2016 Drought. Regionalization of $d v / v$ changes (Jan 2012- Jan 2017) during California's worst drought. GPS stations move toward center of aquifer. Symbols are same as in Fig. 3. 